\title{
Taking the Agenda Forward: The Roundtable on Separated Children Seeking Asylum in Canada
}

\author{
Judith Kumin and Danya Chaikel
}

\begin{abstract}
On October 15 and 16, 2001, the National Roundtable on Separated Children Seeking Asylum in Canada was held in Ottawa. The meeting was organized by the Child Welfare League of Canada, International Social Service Canada, and the United Nations High Commissioner for Refugees (UNHCR) Branch Office in Canada. The organizers brought together immigration officials, child welfare professionals, and refugee advocates, in an effort to build partnerships and improve awareness of the problem of separated children seeking asylum in Canada. Participants discussed ways to resolve the tension between immigration and child protection concerns, as well as how to develop a consistent approach to the issue across Canada. Senator Landon Pearson generously agreed to host the event.
\end{abstract}

\section{Résumé}

Une table ronde intitulée National Rountable on Separated Children Seeking Asylum in Canada ( "Table ronde nationale sur des enfants séparés cherchant asile au Canada ») s'est tenue à Ottawa les 15 et 16 octobre 2001. La réunion a été organisée de concert par la Ligue pour le bien-être de l'enfance du Canada, Service Social International Canada et le Bureau canadien du Haut Commissaire pour les réfugiés. Les organisateurs ont pu réunir des représentants $d u$ département de l'immigration, des professionnels $d u$ service de bien-être de l'enfance et des défenseurs du droit des réfugiés dans le but de forger des alliances et de créer une plus grande conscientisation autour du problème des enfants séparés cherchant asile au Canada. Les participants ont débattu des moyens à adopter pour mettre fin à la tension existant entre immigration et protection des droits des enfants, et aussi pour développer une approche au problème qui soit cohérente à travers tout le Canada. Le sénateur Landon Pearson a très généreusement accepté de se faire l'hôte de du programme.

$\mathrm{U}$ ntil the summer of 1999, child refugee claimants who arrived in Canada without parents or other guardians attracted little attention or concern. Then, in July and August 1999, 134 separated Chinese youth, aged between eleven and seventeen, arrived on the shores of British Columbia. They were among the 599 migrants who traveled on four unseaworthy ships that summer.

The passengers on the first boat, including many children, were released after they applied for refugee status. Most disappeared, presumably to the United States. The federal Minister of Citizenship and Immigration decided that subsequent arrivals would be detained. The provincial Ministry of Children and Families, considering that detention would not be in the children's best interests, took responsibility for the youngsters and placed most of them in specially established group homes.

Although the care provided by the British Columbia Ministry was exemplary, many of the youth still disappeared, in particular after their applications for refugee status in Canada were turned down. It is presumed that the children yielded to pressure from their parents (still in China) and from the traffickers who brought them to Canada. While there is no certainty about where these 
young people have gone, most evidence points to the Chinatowns of cities like New York and Los Angeles. There, the children may end up in the sex trade or as indentured labourers in restaurants and other businesses, often until their parents' debt to the traffickers is paid off.

The experience with the Chinese youth raised difficult questions about what is in the "best interest" of such children. Article 3 of the Convention on the Rights of the Child (CRC) dictates that all actions must be guided by the principle of the best interest of the child. Is returning children to parents who knowingly put their sons and daughters on dangerous boats, and sold them into slavery-like work, in the children's best interest? Would allowing a child to go free, into the arms of the traffickers, be in the children's best interest? If a child is given refugee or humanitarian status and allowed to remain in Canada, what message does that send to parents in China or elsewhere, who are desperately seeking better lives for their children? How can Canada best assist these vulnerable children?

There are no easy answers to these questions, but they convinced the UNHCR office in Ottawa that the question of separated refugee and asylum-seeking children merited new attention at the policy level in Canada. In July 2001, UNHCR published a discussion paper entitled "Separated Children Seeking Asylum in Canada," which provides an overview of the situation of asylum-seeking children who arrive without parents or guardians, identifies issues which deserve attention, and makes proposals for further action.

The report highlights the frequent tension between immigration control imperatives and child welfare concerns, and the absence of opportunities for immigration officials and child welfare professionals to exchange views on matters concerning asylum-seeking children. UNHCR therefore decided to provide a forum where these disparate groups could come together, and did so in partnership with two other organizations: the Child Welfare League of Canada, a national umbrella organization grouping provincial and private child welfare agencies; and International Social Service Canada, a non-governmental social-work agency, which operates in the countries of origin of many of the children who seek asylum in Canada.

Together, the three agencies decided to convene a roundtable, with the goals of improving awareness of the issue of separated children seeking asylum in Canada and addressing these children's protection concerns. The aim was to bring together immigration officials, child welfare professionals, and refugee advocates who could help develop a more consistent approach to separated asylum-seeking children in Canada. Senator Landon Pearson generously agreed to host the event.

In the course of a day and a half, the Roundtable participants examined the following topics:

- the principle of the best interest of the child in the context of separated asylum-seeking children;
- Canadian practice with respect to identification, referral to care, and guardianship;

- detention;

- the Immigration and Refugee Board proceedings and the role of the Designated Representative;

- the return of separated children to their country of origin.

Throughout the discussion of these topics, a number of recurrent themes emerged. The first was the fact that the CRC establishes that the best interest of the child should be a primary consideration at all stages of the process. But "a primary consideration" is not the same as "the primary consideration," and participants agreed that interpretation and application of this principle is the single most difficult challenge in dealing with separated children.

It was also pointed out that in Canada, as in other countries, there is a lack of reliable data on the scope of the problem of separated asylum-seeking children. Data provided by Citizenship and Immigration Canada (CIC) and the Immigration and Refugee Board (IRB) are partial at best. A need therefore exists for the authorities at all levels to devote attention to gathering such information and making it available.

A major theme discussed at the Roundtable was the tension between immigration and child welfare concerns, which traditionally has made it hard to find solutions to problems concerning separated asylum-seeking children. This has been compounded by the difficulty in achieving a consistent national approach in Canada to standards of care for these children. This is due to federal/provincial jurisdictional issues, including the distinct legislative and administrative child welfare frameworks in each province as well as continuing disagreement on respective responsibilities for funding and delivery of care to separated asylum-seeking children. The need for the federal government to take a leadership role on this issue and for greater federal/provincial cooperation was emphasized.

Finally, throughout the discussion, the question of resources was raised. Adequate resources should be allocated to providing care and support for separated asylum-seeking children. While the numbers of such children in Canada appear still to be relatively modest, they have been growing without a corresponding increase in the financial and human resources devoted to meeting the needs of this vulnerable group.

The keynote speaker, Jacqueline Bhabha, Executive Director of the Human Rights Committee of Harvard University, drew attention to the particularly precarious position of separated child asylum seekers. She pointed 
out that while "childhood" occupies a special place in life, with distinct requirements and privileges, we live in a world in which many social evils increasingly affect children. Poverty, forced military recruitment, the sex trade, and police brutality were cited as examples. She deplored the contradiction between the "sentimentalization" of our own children and the tendency toward "collective indifference" to other people's children - a contradiction particularly evident in the case of separated child asylum seekers.

Relatively little is known about the phenomenon of separated child asylum seekers, and this relative ignorance is itself noteworthy. From what is known, separated children have a lower success rate in asylum claims than accompanied children or adults, but also a lower removal or deportation rate. In other words, they tend to remain in host countries, but in a precarious situation, often without access to full welfare benefits or adequate protection. In many European states, separated children receive some form of humanitarian status; in the United States and Canada, many separated children stay without a regular status at all.

For the most part, children seeking asylum flee for the same reasons as adults - to escape war, persecution, ethnic strife, and civil upheaval. The main countries of origin of separated child asylum seekers generally match those generating adult flows of persons seeking protection such as former Yugoslavia, China, Sri Lanka, and Somalia. But the increase in numbers of separated children seeking asylum seems disproportionately large. In the absence of conclusive research, one can only speculate as to the explanation for this. Bhabha suggested three reasons. First, the nature of contemporary war is changing, with civilians, and especially vulnerable civilians, increasingly targeted and affected. Second, the growing difficulty of claiming asylum in developed states because of stringent visa requirements, checks on carriers, militarized borders, and other escalating immigration controls has led to increased dependence by asylum seekers on the costly services of smugglers and traffickers. Families may be able to afford to send only one member to safety, and may send a child as a priority. Third, the forces of globalization may contribute to the growth in numbers of vulnerable children, as structural adjustment policies and the disintegration of traditional sources of security and employment place rising numbers of children at risk.

Bhabha expressed concern about how the tension between immigration enforcement imperatives and child protection concerns affects separated child asylum seekers. Her tentative finding was that it produces an indeterminate limbo in which children are marginalized and have to struggle for certainty, for long-term plans, and even for rights. She concluded that the "policy incoherence" which creates this state of affairs urgently needs systematic attention.
Following the keynote speech, a presentation on the implications for separated children and adolescents of the best-interest principle enshrined in the CRC was made by Wendy Ayotte, UNHCR consultant. She recalled that Article 3 of that Convention states that:

In all actions concerning children, whether undertaken by public or private social welfare institutions, courts of law, administrative authorities or legislative bodies, the best interest of the child shall be a primary consideration.

She drew attention to three other basic principles of the CRC: non-discrimination (Article 2), the right to life (Article 6), and the right of the child to express his or her own views (Article 12).

Ayotte recalled the importance of the CRC as the principal instrument setting out the internationally recognized rights of children, and the importance of Article 3 as a tool for the interpretation of the other articles of the Convention. She stressed that the best interest principle needs to be applied in a case-specific manner, and that while the views of the child must be taken seriously, they will not always prevail. The appointment of a qualified guardian was identified as key to ensuring that the child's best interest is considered in all aspects of life: in terms of health, psychosocial well-being, family relations, education, legal representation, and the immigration and refugee process. Since detention cannot be construed as being in a child's best interest, Ayotte emphasized that creative alternatives to providing secure care for at-risk children should be developed. Training for all those who deal with separated asylum-seeking children is essential. This includes lawyers, CIC and IRB officials, designated representatives, and child-care professionals. Finally, she urged that consideration be given to developing a national protocol on separated children seeking asylum in Canada, to ensure protection of their rights as children.

Many important points emerged from the discussion:

There is a need for a consistent approach to the definition of a separated child. The CRC, to which Canada is party, defines a child as under the age of eighteen. The age range for child protection in Canada, however, varies from under nineteen in British Columbia to under sixteen in Ontario. The cut-off age for care in Ontario was identified by participants as a significant protection gap. Furthermore, particular attention should be paid to properly identifying separated children, including those who are accompanied or met in Canada by adults who are not their parents. More consideration should be given to appropriate age-assessment methods, since 
there are conflicting views on the accuracy of medical techniques used to determine age. It was recommended that ageassessment tests be culturally sensitive and take into account, for instance, the different level of physical development of children who have been undernourished. Also, the question was raised as to whether a child needs to give consent before bone scans or dental examinations are administered.

2. There is a need to achieve a more consistent response when separated asylum-seeking children come to the attention of Canadian authorities. The situation in Ontario, where there is no mechanism to provide protection and care for children who are sixteen and seventeen years old, was the subject of discussion, and was contrasted with procedures in British Columbia and Quebec. A task force in Ontario, which met during late 2000 and early 2001, proposed a protocol to meet the needs of separated asylum-seeking children who do not come within the jurisdiction of the child welfare agencies. This effort was reviewed and could usefully be the subject of further discussion.

3. There needs to be a clearer understanding of the nature and scope of guardianship in the context of separated children. The appointment of a legal guardian was identified as essential to identifying and responding to the issues affecting the best interest of these children. Practice is different in each of the provinces, with a variety of strengths and weaknesses.

4. Training and sensitization on child protection issues would be beneficial for all parties dealing with separated children (CIC, IRB, lawyers, NGOs). Many professionals working with separated children have extensive human rights or refugee protection training, but lack experience with children and are not necessarily sensitive to their specific needs. This is crucial if child-appropriate interviews are to be conducted, when dealing with trauma, and when assessing placements. As well, it was suggested that new ways of soliciting evidence from children are needed, especially from the very young, since the IRB process can be intimidating for a child and could cause further trauma. Several participants felt that it was not appropriate to compel children, particularly young children, to give evidence in IRB proceedings. Others suggested that the experience which has been gathered in other domains with regard to eliciting evidence from child witnesses could be useful in the refugee area.

5. It was suggested that establishment of a "case management team" for each child would be helpful and would enable concerned parties to share knowledge of the child's situation. Such a team could better coordinate legal and administrative procedures and more effectively assist the child. It would also enable children to build relationships of trust with individuals whom they see on a regular basis.

6. Participants agreed that detention of separated children is inherently undesirable, and that all alternatives should be explored before a child is detained. Recent examples of detention practice in several provinces were raised, and many participants felt that they represented an inappropriate response which was contrary to the best interest of the children concerned. The absence of data on the detention of children was identified as a problem, and CIC was urged to gather and make available data on the number and locations of separated children detained.

In the context of the discussion on detention, it was noted that the best-interest principle is complicated by increased instances of smuggling (organized movement of migrants across borders) and trafficking (where there is coercion and/or slavery-like working conditions). Some participants felt that the obligation to protect children from abuse could make detention of some sort necessary. Other participants suggested that while it may be necessary in some cases to place restrictions on the freedom of movement of unaccompanied children who are at risk, the challenge lay in coming up with ways to achieve this objective without resorting to detention, which some claim in effect criminalizes the victims. In any event, the appropriateness of detention of a separated child should be based on an individual assessment, taking into account all of the child's circumstances.

It was recommended that $\mathrm{CIC}$, child welfare authorities, and NGOs collaborate to develop viable alternatives to detention. A "safe house" model used in England was cited as an example. The "buddy system" was also proposed as a measure to offer some protection against trafficking. This could involve older children who understand the risks of unaccompanied migration and who can share their experiences and offer some guidance to newly arrived children. This can be also a very good strategy for trust-building.

7. A discussion on the role of the Designated Representatives (DRs), who are appointed by the IRB to represent separated children, focused on the ways to enhance the effectiveness of these representatives in protecting the best interest of the child in IRB proceedings. It was agreed that there is a need for training of the representatives with respect to the refugee process and procedures generally and for their role in this context. Some participants thought that the minimum age requirement for DRs (eighteen years) is too low. Concern was expressed that some DRs lack the necessary cultural knowledge or sensitivity. It was also suggested that IRB members be trained on the role of DRs, and that the IRB should monitor the suitability and effectiveness of DRs. Many participants were concerned about the regulation stipulating that when children turn eighteen, they immediately lose their right to have a DR, even if they were 
already assigned one. It was recommended that whenever possible, those appointed as DRs should be professional individuals such as social workers and psychologists. The practice in Quebec and British Columbia, where child welfare agencies and NGOs are often appointed as DRs, was considered to be a positive approach.

8. The IRB was urged to consider revising its Child Refugee Claimant Guidelines to include substantive issues, akin to the United States Immigration and Migration Services Guidelines. It was also urged that the IRB designate and train specialized members to hear children's claims. In other areas of law (such as family and criminal law), judges are required to have particular expertise, and this could by analogy be extended to cases involving separated children seeking asylum.

9. With respect to the return of separated children to their country of origin, a comprehensive pre-removal risk review following the best interest principle should be conducted. Return of separated children should occur only it is in the best interest of the child, has been properly arranged, and can take place in safe conditions. This may involve family tracing and counselling for the child and his or her family. Federal authorities were encouraged to make available data on the numbers of children removed to countries of origin, as well as to third countries (usually the United States).

10. CIC was invited to take a leadership role in pursuing discussions with the provinces. It was suggested that a tripartite working group (CIC, provincial representatives, and NGOs) could usefully be set up to pursue the discussion.

11. After a day and a half of intensive deliberations, delegates agreed on the need to pursue specific actions, with a view to ensuring consistent treatment of separated children seeking asylum across Canada. The Roundtable was a first step, and brought together key stakeholders. For the first time in Canada, this network of concerned individuals and agencies shared valuable knowledge from their diverse regional and sectoral backgrounds. They now face the challenge of developing a Canadian model which will ensure that the rights of separated children seeking asylum in this country are protected.

\section{Note}

1. Wendy Ayotte, Separated Children Seeking Asylum in Canada (Ottawa: UNHCR July 2001). Available on request fromUNHCR in Ottawa.

Judith Kumin is the representative in Canada of the United Nations High Commissioner for Refugees.

Danya Chaikel is a CANADEMjunior professional consultant in the UNHCR office in Ottawa. Her background is in human rights, with a special interest in the trafficking of migrants. 